pulled from the spiritual soil, many small faith enterprises are shaken by its loss and will struggle to survive. Let us hope that out of this closure is born a new enterprise which will indeed help us towards the church of the $21^{\text {st }}$ century.

Blan MacDonagh

Diocesan Resource Centre, Catholic Diocesan Centre, Adelaide.

\title{
George Knight Library
}

The Pacific Theological College strives to uphold the good reputation of its programmes, as the most advanced theological training available in the South Pacific islands, by providing a quality theological library in terms of both the collection and the services offered to the students. The use of the library by students from other theological institutions and Bible colleges in and around Suva is testimony to the value of the library collection and the library staff's ability to assist people find the materials they need.

The George Knight Library, named in honour of the college's first principal, was opened in 1972. It now has about 20,000 books and receives about 100 periodical titles. It also has a computer database on Pacific church history, a computer-based index to religious periodical literature, access to the University of the South Pacific Library catalogue via modem, and a growing collection of microfilms, microfiche and videos related to the courses offered by the college. These developments using newer technology have become essential for the research expected from students studying at advanced levels.

t The founders of Pacific Theological College intended the Library to provide advanced theological training for Pacific people that was both contextual and comparable to what they would receive elsewhere. The library tries to support these two objectives, but is finding it increasingly difficult because of lack of finance. We are struggling to purchase the new publications required by faculty for background reading for their courses.

We are also unable to build up a collection of relevant material generated by Pacific Islanders themselves (such as theses written at other institutions) and are aware that student research is hampered by a lack of library resources, including reference books and microfilms of historical records.

The library has developed to its present standard because of the contributions of many people throughout its history who have understood the importance of an adequate library for a sound theological education. It continues to rely on the generosity of its supporters.

\section{Computer Project}

The Pacific Theological College has 10 computers available for student use. Networking throughout the College will provide a more efficient system, particularly with increased use of the computerised catalogue, and will reduce costs on printers and provide for email.

The funding for this project has come from NMZ Hamburg, a total of FJ $\$ 43,778.71$. Maintenance for the computers will come from the annual budget of the College. Our special thanks goes to the Mission Board in Hamburg and to Wolfgang Kruger for implementing this project as part of the development of PTC,

Adapted from the account which appeared in the June 1997 issue of the PTC News : the Newsletter of the Pacific Theological College 